\title{
European Legal Order with no Mercy for Member States' Budget Concerns
}

\author{
Otmar Thömmes, Deloitte Touche Tohmatsu, New York
}

Let us imagine a taxpayer who has taken advantage of a tax favourable investment scheme over a period of 10 years. The scheme has allowed her to significantly reduce her annual tax payable. The tax authorities argue the scheme constitutes abuse and that the tax benefits it has conferred should therefore be recaptured. The case ends up in tax court, where the taxpayer claims that if the judge were to decide in favour of the tax authorities, the consequences of that decision should be limited to future fiscal years, and should not affect past years. The financial implications of a decision imposing additional tax payable representing the aggregate tax savings enjoyed during the previous 10 years clearly would seriously jeopardize the taxpayer's financial well being.

In these circumstances, how likely is it that a tax court would impose a time restriction on the consequences of a decision in favour of the tax authorities? Assuming new legislation has not been introduced that would allow the taxpayer to mount an argument against its retroactive application on constitutional grounds (an argument that should always be made where recently adopted anti-abuse legislation is applied to transactions completed before it became effective), our unlucky taxpayer would have no chance of success. And for good reason, because the legality of a taxpayer's activities is a matter to be determined by the courts and any violation of legislation in effect at the time taxation was imposed must be evaluated in the context of the application of the existing law.

Why would any legal system show mercy to a taxpayer in violation of the law, based on the argument that the financial consequences for the taxpayer would otherwise be too harsh? Why should the extent of discretionary relief afforded to the violator be greater because the benefits derived from the violation were so great? Logic would suggest that the longer the violation of law continued, the harsher the consequences should be and, thus, the more generous and merciful the legal system would have to be to provide relief from those consequences. In effect there would have to be a 'volume discount' for violations. In reality, how long could a legal system that made such accommodations survive? Mercy is clearly an essential part of any legal system - but it should be restricted and never become a reward for, and therefore an incentive to, unlawful behaviour.

However, let us take a look at the other side of the coin. Suppose a taxpayer overpaid tax for a similar 10year period because of a feature of the domestic tax legislation of her country of residence that was in violation of EC law when the tax was levied. Assume further that the taxpayer's case ultimately comes before the European Court of Justice (ECJ), which rules that the domestic law indeed was in violation of the EC Treaty and therefore inapplicable. If, in these circumstances, the ECJ were to limit the consequences of its decision to future fiscal periods, one would have to say that a different kind of logic was at work. But if equality of application is a fundamental principle of our legal systems in Europe, why should this principle not apply in the field of EC law?

These questions should soon be answered, as the ECJ will be ruling on in the Meilicke case, a case with striking similarities to our second scenario (C-292/04). The case concerns a German taxpayer who was denied an imputation tax credit for dividends received from a company resident in another EU Member State, while a full imputation tax credit would have been available had the taxpayer invested in the shares of a German company.

Long before the ECJ issued its decisions in the Verkooijen (C-35/98) and Manninen (C-319/02) cases in 2000 and 2004, respectively, it was clear that the German corporation tax system's denial of crossborder relief for EU dividends was in violation of primary EC law. An initial attempt by the German legislature in 1993 to replace Germany's non-compliant imputation system with an alternative EC-compliant system that would have provided for a deemed credit of $3 / 7$ of the dividend, failed in the legislative proceedings, mainly because of the budgetary concerns over the proposed imputation credit. Without doubt, the longer the German government managed to keep the non-EC compliant system in place, the greater the revenue to be derived and the better for the national budget. A 'wait and see' approach was therefore adopted, the thought being that should the ECJ ultimately rule against Germany, the law could still be amended for the future, but for the time being time, its benefits for the German fisc could be retained. It is precisely because of this 'wait and see' attitude, coupled with unawareness of the primacy of EC law, that the potential refund claims from a successful challenge to the domestic rules have grown to their current magnitude. 
ECJ Advocate General Stix-Hackl is to be commended for her courage in adhering to the principles of the European legal system and recommending to the ECJ, in her opinion of 5 October 2006 in the Meilicke case, that the arguments raised by the German government against the application of primary EC law to past periods should be rejected. In its press release of 5 October 2006 (the day on which the AG
Stix-Hackl submitted her opinion to the Court), the German government complained that the opinion ran contrary to all 'Sachverstand' (English 'educated reason' or 'reason'), was 'completely incomprehensible' and was 'in violation of the fundamental interests of a Member State and its citizens'. Perhaps it is time for the Court to make it clear to the German tax authorities whose fundamental rights are at risk. 